\title{
Microwave-Assisted Extraction of Fatty Acids from Cultured and Commercial Phytoplankton Species
}

\author{
Jéssica Aparecida Moretto ${ }^{1} \mathbb{D}$, Alexander Ossanes de Souza ${ }^{1}$, Lucas Moraes Berneira ${ }^{2}$, Luiz Gustavo G. Brigagão ${ }^{3}$, \\ Claudio Martin Pereira de Pereira ${ }^{2}$, Attilio Converti ${ }^{4, * \mathbb{D}}$ and Ernani Pinto ${ }^{1,5} \mathbb{D}$
}

check for

updates

Citation: Moretto, J.A.; de Souza,

A.O.; Berneira, L.M.; Brigagão,

L.G.G.; de Pereira, C.M.P.; Converti,

A.; Pinto, E. Microwave-Assisted

Extraction of Fatty Acids from

Cultured and Commercial

Phytoplankton Species. Appl. Sci.

2022, 12, 2407. https://doi.org/

10.3390/app12052407

Academic Editor: Sébastien Jubeau

Received: 7 January 2022

Accepted: 15 February 2022

Published: 25 February 2022

Publisher's Note: MDPI stays neutral with regard to jurisdictional claims in published maps and institutional affiliations.

Copyright: (C) 2022 by the authors. Licensee MDPI, Basel, Switzerland. This article is an open access article distributed under the terms and conditions of the Creative Commons Attribution (CC BY) license (https:// creativecommons.org/licenses/by/ $4.0 /)$.
1 Center of Nuclear Energy in Agriculture (CENA), University of São Paulo (USP), Piracicaba 13416-000, Brazil; jessica.moretto@usp.br (J.A.M.); alexandersouza@usp.br (A.O.d.S.); ernani@usp.br (E.P.)

2 Lipidomic and Bioorganic Laboratory, Center of Chemical, Food and Pharmaceutical Sciences, Forensic Chemistry, Federal University of Pelotas, Pelotas 96010-610, Brazil; lucas.berneira@hotmail.com (L.M.B.); claudio.martin@ufpel.edu.br (C.M.P.d.P.)

3 Department of Clinical and Toxicological Analysis, Faculty of Pharmaceutical Sciences, University of São Paulo (USP), Av. Prof. Lineu Prestes 580, Bl. 17, São Paulo 05508-900, Brazil; gustavogb@usp.br

4 Department of Civil, Chemical and Environmental Engineering, Pole of Chemical Engineering, University of Genoa, Via Opera Pia 15, 16145 Genoa, Italy

5 Food Research Center (FoRC-CEPID), University of São Paulo (USP), São Paulo 05508-220, Brazil

* Correspondence: converti@unige.it

\begin{abstract}
Background: The extraction of fatty acids from microalgae and cyanobacteria is mostly performed with organic solvents and laborious procedures. Microwave-assisted extraction (MAE) can be a more effective and environmentally friendly process than traditional extraction (TE), which uses a large volume of solvent and conduction heating. Freshwater phytoplankton inhabits diverse aquatic environments and is a promising source of fatty acids and green precursors in the synthesis of biofuel, including cyanobacterial biomass. Therefore, the aim of this study was to investigate the potential of MAE to extract fatty acids from a Chlorella sp. microalga and two cyanobacteria, namely, Arthrospira sp. and Sphaerospermopsis torques-reginae, for biodiesel production. For this purpose, the lipid content and fatty acid profile of these strains were compared after treating biomass with the two extraction methods. (2) Methods: MAE and TE were used as extraction procedures; gas chromatography-mass spectrometry was used to assess the fatty acid profiles, and X-ray spectroscopy was used to analyze biomass. (3) Results: Although the fatty acid profile of the oil obtained by TE showed higher concentrations of fatty acids, the MAE method was able to extract more types of fatty acids. The variety of fatty acids extracted by the MAE, especially those with unsaturated chains, allowed for better quality biodiesel, presenting advantages over previous methods and studies. According to the analyses, essential fatty acids 16:0, 16:1, and 18:2 were found to be abundant in both cyanobacterial strains and in microalga, showing potential for biofuel production. Additionally, metal composition was determined as its content may indicate potential pro-oxidant influence in biofuel production. (4) Conclusions: MAE is a useful and green strategy to extract fatty acids from freshwater phytoplankton. Cyanobacteria can also be a beneficial source of fatty acids for biodiesel synthesis.
\end{abstract}

Keywords: microwave-assisted extraction; cyanobacteria; microalgae; lipids

\section{Introduction}

The increasing energy demand, the expected shortage of conventional fossil fuels, and the recognized effects on climate global emergency has led to the development of novel energy sources, including biodiesel [1,2]. Biofuel production from phytoplankton biomass is an extremely promising and important issue due to the relevance it has gained with the increase in petroleum prices and its environmental advantages $[3,4]$.

In this sense, microalgae and cyanobacteria are widespread photosynthetic organisms with high oil content. The advantage of using these organisms is that they can grow quickly 
in freshwater, seawater, or wastewater. Moreover, their cultivation contributes to reducing the presence of greenhouse gases in the atmosphere as they convert approximately 2 tons of inorganic $\mathrm{CO}_{2}$ into 1 ton of biomass [5-7]. Therefore, microalgae and cyanobacteria can be a promising alternative for biodiesel production as well as conventional raw materials $[1,8-10]$.

Current methods regarding biodiesel synthesis from microalgae and cyanobacteria biomass are time-consuming and require large amounts of organic solvents as procedures rely on an initial step of oil extraction followed by transesterification to synthesize fatty acid alkyl esters [2,3]. In this sense, "green" techniques such as ultrasound-assisted transesterification and microwave irradiation have been studied to overcome the disadvantages associated with conventional biofuel synthesis $[7,11]$.

Among ecofriendly methodologies, the application of microwave irradiation has a great potential for biodiesel production, as the extraction and transesterification can occur in a single step in situ. This combination not only reduces the synthesis time, solvent amount, and production cost eliminating complex and unneeded steps of the procedure [1,12], but also assists the biodiesel production from microbial biomass through cell wall disruption, rapid and homogeneous heat generation, and pressure, thereby enabling an efficient oil extraction $[8,10,13]$.

Despite the numerous advantages in the use of microorganisms to produce biodiesel, the literature lacks studies involving common freshwater cyanobacteria for this purpose. Therefore, the aim of this study was to investigate the potential of MAE to extract fatty acids from a Chlorella sp. microalga and two cyanobacteria, namely, Arthrospira sp. and Sphaerospermopsis torques-reginae, for biodiesel obtention. Furthermore, two different fatty acid and total lipid extraction methods, i.e., traditional extraction and microwave-assisted extraction, were compared.

\section{Materials and Methods}

\subsection{Chemicals and Standards}

Methanol, $n$-hexane, and potassium hydroxide were purchased from Sigma-Aldrich (St. Louis, MO, USA). A $\mathrm{C}_{4} \mathrm{C}_{24}$ FAME Mix standard was acquired from Supelco (Bellefonte, PA, USA).

\subsection{Cultures and Commercial Samples}

Samples of Arthrospira sp. (batch: 2018092611) and Chlorella sp. (batch: 21461095890) were acquired at commercial grade from Rofimex (Dionísio Cerqueira, Brazil). Sphaerospermopsis torques-reginae was isolated from a reservoir in the state of Pernambuco, Brazil, and cultivated in the laboratory. This strain was cultivated in ASM-1 medium at $22 \mu \mathrm{mol}$ photons $\mathrm{m}^{-2} \mathrm{~s}^{-1}$ using a 12:12 $\mathrm{h}$ (light/dark) photoperiod at $25^{\circ} \mathrm{C}\left( \pm 1^{\circ} \mathrm{C}\right)$ [14-16].

\subsection{Traditional Extraction (TE) of Lipids and Fatty Acids}

The biomass of each strain was lyophilized, and $30 \mathrm{mg}$ of each dry biomass was resuspended in $1 \mathrm{~mL}$ of ultrapure water (Milli-Q, Merck Millipore, Billerica, MA, USA). Total lipids were extracted using a modified method of Bligh and Dyer [17-19].

The oil resulting from the extraction process was derivatized, and the fatty acids were analyzed as methyl-esters (FAMEs). The transesterification was carried out by adding $1.8 \mathrm{~mL}$ of a methanolic solution of $5 \% \mathrm{HCl}$ [20]. In addition, $200 \mu \mathrm{L}$ of chloroform containing nonadecanoic acid was added. Nonadecanoic acid is not produced by cyanobacteria, so it was used as an internal standard.

The reaction was carried out at $100{ }^{\circ} \mathrm{C}$ for $15 \mathrm{~min}$. After this step, $1 \mathrm{~mL}$ of hexane $+1 \mathrm{~mL}$ of ultrapure water were added to the mixture. Then, the tubes were shaken for $1 \mathrm{~min}$, and the aqueous and organic phases were separated by centrifugation at $5000 \mathrm{rpm}$ for $15 \mathrm{~min}$. The reactions were performed in triplicate. The organic phase was transferred to an amber vial for analysis by gas chromatography coupled with mass spectrometry (GC-MS). 


\subsection{Gas Chromatography-Mass Spectrometry}

The extraction triplicates of each sample were analyzed by a Gas ChromatographMass Spectrometer, model GCMS QP2010 (Shimadzu, Kyoto, Japan), using helium as the carrier gas and an RTX-5MS capillary column as the stationary phase. Temperatures of the injection port and detector were 220 and $240{ }^{\circ} \mathrm{C}$, respectively. GLC temperature program: $50-130{ }^{\circ} \mathrm{C} / 20^{\circ} \mathrm{C} \mathrm{min}-1,130-220{ }^{\circ} \mathrm{C} / 5^{\circ} \mathrm{C} \mathrm{min}^{-1}$ (10 min hold), $33 \mathrm{~min}$ run time. Biodiesel constituents were identified using the $\mathrm{C}_{4} \mathrm{C}_{24}$ FAME Mix standard and a NIST-17 spectral library. Semi-quantification of samples was made by area normalization, and results were expressed as percentage $[18,20,21]$.

\subsection{Microwave-Assisted In Situ Extraction and Transesterification}

Briefly, $500 \mathrm{mg}$ of the samples was mixed with $10 \mathrm{~mL}$ of a $2 \%(w / v)$ methanolic solution of potassium hydroxide. The mixture was introduced in an open vessel microwave digestion system (CEM, Charlotte, NC, USA) and subjected to $100 \mathrm{~W}$ for 5 min under constant stirring, according to Pacheco et al. [22]. Afterward, the material was transferred to a separatory funnel, and the biodiesel was extracted using $10 \mathrm{~mL}$ of $n$-hexane. Finally, samples were dried under reduced pressure. All analyses were performed in triplicate $(n=3)[19,21]$. In this procedure, the extraction and transesterification processes took place simultaneously.

\subsection{X-ray Spectroscopy}

Cyanobacterial and microalgal biomasses were analyzed via X-ray spectroscopy, model EDX-720 (Shimadzu, Kyoto, Japan), using an X-ray beam energy of 20 to $40 \mathrm{keV}$ [23,24].

\subsection{Statistical Analysis}

Statistical analysis was performed using analysis of variance (ANOVA) followed by Tukey's test. The results, expressed as mean \pm standard deviation, were considered statistically significant with $p \leq 0.05$.

\section{Results}

\subsection{Lipids and Fatty Acids}

The composition of lipids from microalgae and cyanobacteria can vary according to the fatty acids that compose them, the species, and even the lipid extraction method. Therefore, to prove good efficiency and possible advantages of microwave-assisted extraction (MAE), the traditional extraction (TE) was also carried out for comparative purposes. The lipid content of Chlorella sp., Arthrospira sp., and S. torques-reginae ranged between $11 \%$ and $23 \%$.

As shown in Figure 1, and according to percentage obtained from GC-MS analysis of triplicate extractions and statistical analyses, TE was more efficient than MAE in extracting total lipids from Chlorella sp. and S. torques-reginae, but there was no statistical difference between the results of these methods for Arthrospira sp. As expected, the microalga Chlorella sp. had a higher concentration of lipids than the cyanobacteria. Nevertheless, it is possible to observe that the use of cyanobacterial biomass is also a clean and sustainable alternative to produce biodiesel.

Given the abundance of Sphaerospermopsis sp. in bloom episodes and the satisfactory percentage of lipids detected in S. torques-reginae to produce biodiesel, this strain was also chosen to compare the MAE and TE methods for fatty acid extraction.

Several fatty acids were identified in the $S$. torques-reginae extract obtained by TE, most of them being saturated fatty acids (SAFAs) such as 16:0 and 18:0, while polyunsaturated fatty acids (PUFAs) such as 18:2 and 18:3 were present in intermediate contents, and monounsaturated fatty acids (MUFAs) such as 16:1 and 18:1 in the lowest ones (Table 1).

Analyzing the fatty acid profile of the strains was essential, as it determined the quality of the biofuel. Although the fatty acid profile of the oil obtained by TE showed higher concentrations of fatty acids, the MAE method was able to extract more types of fatty acids. 


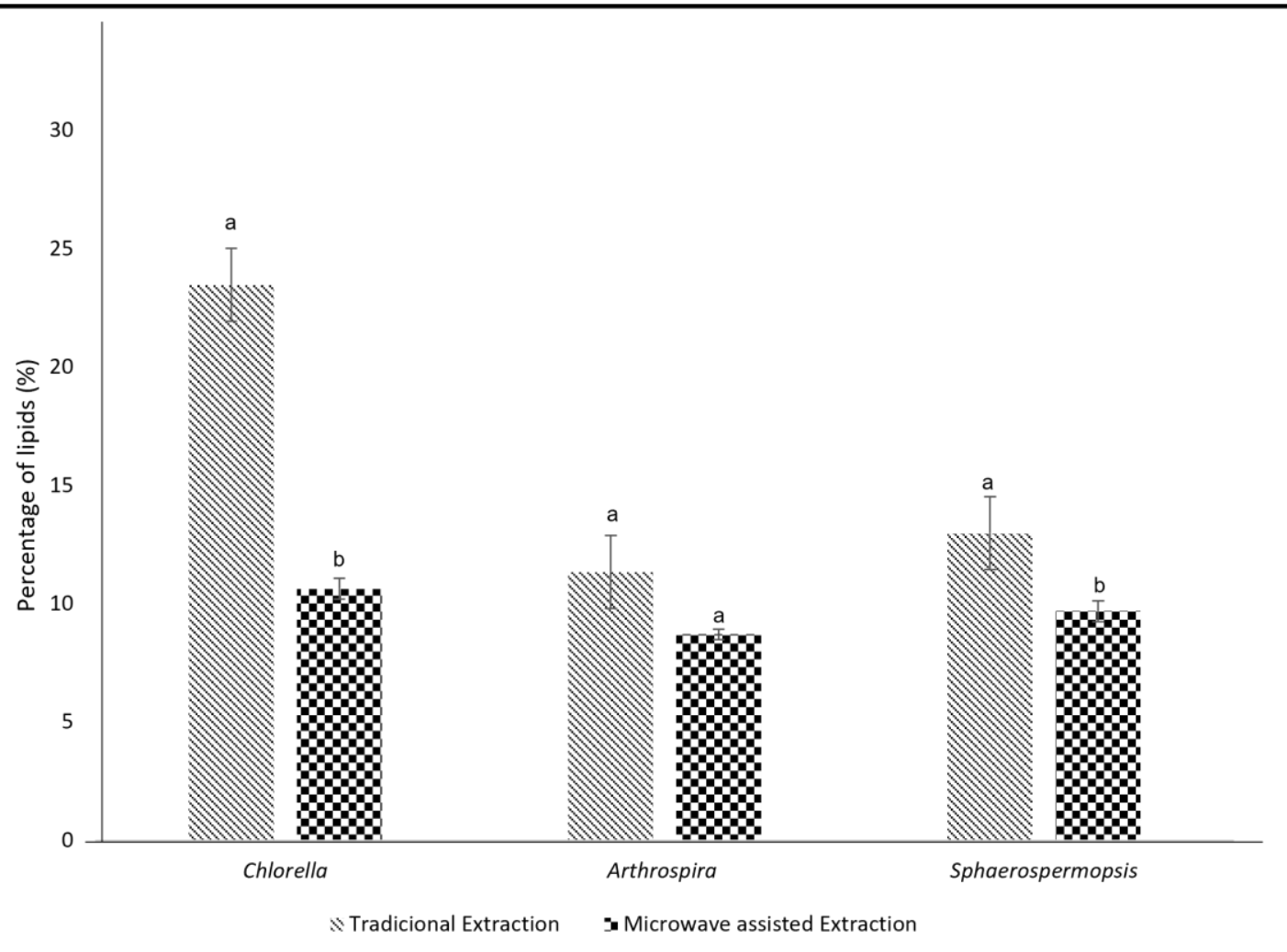

Figure 1. Comparison of lipid recovery yields from Chlorella sp., Arthrospira sp., and Sphaerospermopsis torques-reginae using traditional extraction and microwave-assisted extraction obtained by GC-MS $(\mathrm{n}=3)$. Different letters indicate significant differences in the results $(p \leq 0.05)$.

Table 1. Average composition (\% of area) of fatty acids obtained by traditional and microwaveassisted extractions of cyanobacterial and microalgal biomass $(n=3)$.

\begin{tabular}{|c|c|c|c|c|c|}
\hline \multirow{2}{*}{\multicolumn{2}{|c|}{ Fatty Acid }} & \multirow{2}{*}{$\begin{array}{c}\text { Arthrospira sp. } \\
\text { MAE }\end{array}$} & \multirow{2}{*}{$\begin{array}{c}\text { Chlorella sp. } \\
\text { MAE }\end{array}$} & \multicolumn{2}{|c|}{ S. torques } \\
\hline & & & & MAE & TE \\
\hline C10:0 & Capric acid & $0.11 \pm 0.01^{\mathrm{a}}$ & $0.20 \pm 0.01^{b}$ & n.a. & n.a. \\
\hline C14:0 & Myristic acid & $0.93 \pm 0.00^{\mathrm{a}}$ & $1.46 \pm 0.18^{\mathrm{b}}$ & $2.44 \pm 0.10^{\mathrm{c}}$ & n.a. \\
\hline C15:0 & Pentadecanoic acid & $0.44 \pm 0.00^{\mathrm{a}}$ & $0.88 \pm 0.06^{b}$ & n.a. & n.a. \\
\hline $\mathrm{C} 16: 0$ & Palmitic acid & $37.41 \pm 0.29^{a}$ & $18.30 \pm 0.29^{b}$ & $34.85 \pm 0.09^{c}$ & $54.36 \pm 0.10$ \\
\hline C16:1 & Palmitoleic acid & $10.77 \pm 0.24^{\mathrm{a}}$ & $11.86 \pm 0.23^{b}$ & $8.92 \pm 0.46^{\mathrm{c}}$ & $11.17 \pm 0.11$ \\
\hline $\mathrm{C} 17: 0$ & Heptadecanoic acid & $0.76 \pm 0.02^{\mathrm{a}}$ & $0.51 \pm 0.04^{\mathrm{b}}$ & n.a. & n.a. \\
\hline C17:1 & Heptadecaenoic acid & $0.78 \pm 0.01^{\mathrm{a}}$ & $1.86 \pm 0.13^{b}$ & n.a. & n.a. \\
\hline C18:0 & Stearic acid & $2.13 \pm 0.04^{\mathrm{a}, \mathrm{b}}$ & $1.55 \pm 0.07^{\mathrm{c}}$ & $2.87 \pm 0.29^{b}$ & $12.59 \pm 0.19$ \\
\hline C18:1 & Oleic acid & $1.11 \pm 0.04^{\mathrm{a}}$ & $1.33 \pm 0.04^{b}$ & $7.49 \pm 0.15^{c}$ & $2.55 \pm 0.09$ \\
\hline C18:2 & Linoleic acid & $25.83 \pm 0.17^{\mathrm{a}}$ & $31.93 \pm 0.47^{b}$ & $33.94 \pm 0.26^{c}$ & $5.89 \pm 0.11$ \\
\hline C18:4 & Stearidonic acid & $0.19 \pm 0.01^{\mathrm{a}}$ & $0.82 \pm 0.14^{\mathrm{b}}$ & n.a. & n.a. \\
\hline C20:4 & Arachidonic acid & $0.19 \pm 0.01^{\mathrm{a}}$ & $0.62 \pm 0.00^{b}$ & n.a. & n.a. \\
\hline C21:5 & $\begin{array}{l}\text { Tetracosanolpentaenoic } \\
\text { acid }\end{array}$ & $0.74 \pm 0.00^{\mathrm{a}}$ & $26.82 \pm 1.19^{b}$ & n.a. & n.a. \\
\hline Phytol & & $18.40 \pm 0.16^{\mathrm{a}}$ & $28.01 \pm 2.38^{b}$ & $8.83 \pm 0.28^{c}$ & n.a. \\
\hline$\sum$ SFAs & & $41.79 \pm 0.35^{\mathrm{a}}$ & $22.91 \pm 0.40^{b}$ & $40.13 \pm 0.28^{c}$ & $66.95 \pm 0.16$ \\
\hline$\sum$ MUFAs & & $12.66 \pm 0.18^{a}$ & $15.05 \pm 0.40^{\mathrm{a}}$ & $16.20 \pm 0.47^{b}$ & $13.72 \pm 0.38$ \\
\hline EPUFAs & & $26.96 \pm 0.18^{a}$ & $26.96 \pm 0.18^{a}$ & $35.74 \pm 0.25^{b}$ & $5.89 \pm 0.26$ \\
\hline
\end{tabular}

Note: Results expressed as average \pm standard deviation. n.a.-non-available, SFAs—saturated fatty acid acids, MUFAs - monounsaturated fatty acids, PUFAs - polyunsaturated fatty acids, MAE - microwave-assisted extraction, TE-traditional extraction. Different letters $(\mathrm{a}-\mathrm{c})$ indicate significant differences in the results $(p \leq 0.05)$. 
Table 1 shows that the biofuel would be composed of 14 FAs ranging from $\mathrm{C} 10$ to C21 with SFAs, MUFAs, and PUFAs accounting for 6, 3, and 5 of the detected compounds. In general, the most abundant FAs in samples were palmitic (C16:0), linoleic (C18:2), and palmitoleic (C16:1) acids, which had significant differences in concentration among the samples. Other FAs found in noticeable concentrations were myristic (C14:0), stearic (C18:0), and oleic (C18:1) acids.

Comparison among the classes of FAs revealed that PUFAs were predominant, constituting from $35.74 \pm 0.25 \%$ (S. torques-reginae) to $26.96 \pm 0.18 \%$ (Chlorella sp.) of samples, with almost coincident percentages of n3 and n6 PUFAs. On the other hand, SFAs, mainly in the forms of C14:0 and C16:0, accounted for $41.79 \pm 0.35 \%$ (Arthrospira sp.) to $22.91 \pm 0.40 \%$ (Chlorella sp.). MUFAs corresponded the smallest fraction among the classes, ranging from $16.20 \pm 0.47 \%$ (S. torques-reginae) to $12.66 \pm 0.18 \%$ (Arthrospira sp.).

All the strains showed a good correlation between saturated and unsaturated fatty acids, with a profile similar to that described for some other species of cyanobacteria and microalgae [25-27]. These results may open the way for the use of S. torques-reginae and other cyanobacteria to produce sustainable biodiesel.

\subsection{X-ray Spectroscopy}

As is known, X-ray spectroscopy analysis allows the elemental characterization of different matrices with minimal sample manipulation, reducing possible contamination or use of reagents. This analysis is essential to evaluate the elements present in a raw material, since the presence of some elemental ions can harm the biodiesel production process.

X-ray spectroscopy analysis (Table 2) showed that samples were composed of a wide variety of elements. Elements found in the highest concentrations were calcium (22.07-35.79\%), potassium (21.44-37.80\%), and phosphorus (10.30-15.35\%), while those found in intermediate concentrations were sulfur (11.25-12.59\%), iron (6.25-11.04\%), and chlorine $(4-11 \%)$. Other elements were found in negligible amounts, accounting for a total concentration of only $0.56 \%$.

Table 2. Metal composition (\%) of cyanobacterial and microalgal biomass.

\begin{tabular}{cccc}
\hline \multirow{2}{*}{ Metal } & \multicolumn{3}{c}{ Sample } \\
\cline { 2 - 4 } & Chlorella sp. & Arthrospira sp. & S. torques-reginae \\
\hline Calcium & 35.79 & 22.07 & 31.25 \\
Potassium & 21.44 & 37.80 & 26.42 \\
Phosphorus & 15.35 & 10.30 & 12.03 \\
Sulfur & 11.25 & 12.69 & 11.25 \\
Iron & 11.04 & 6.25 & 8.26 \\
Chlorine & 4.54 & 10.46 & 10.25 \\
Others & 0.56 & 0.42 & 0.54 \\
\hline
\end{tabular}

\section{Discussion}

Microwave technology has enabled the development of faster, safer, and economical methods to extract and convert lipids into biofuel. The rapidly wavering electric field produced by microwaves generates heat due to frictional forces resulting from interand intramolecular movements of dielectric/polar material in the cell's molecules [2,3]. Furthermore, intracellular heating generates water vapor that disrupts the cell from the inside. In turn, this can lead to the electroporation effect, i.e., a considerable increase in the electrical conductivity and permeability of cyanobacterial and microalgal cell wall as well as cytoplasmic membrane resulting from an applied external electrical field $[10,28]$.

The opening of cell membrane makes the extraction of intracellular metabolites efficient, because it forces out compounds from the cell matrix, producing good quality extracts [2]. In general, microwave-assisted extraction (MAE) has been considered a potential alternative to conventional extraction methods to produce biodiesel from microorganisms 
due to (i) reduced extraction time, (ii) reduced solvent usage, and (iii) improved transesterification yield $[10,13,28]$. An alternative to improve the efficiency of MAE would be to increase the amount of organic solvent used, but the MAE method had several advantages over the TE, due to the lower use of organic solvents as well as greater ease, speed, and efficiency, in addition to following the principles of green chemistry to produce biodiesel. In addition to the advantages, we observed that the MAE method allowed the release of more FA compounds, increased the concentration of C18:1 and C18:2, and also allowed the in-situ synthesis of biodiesel.

The variety of fatty acids obtained, especially those with unsaturated chains, allows for better quality biodiesel $[13,29]$. In this sense, this study provided important information on the production of biodiesel from the microalga Chlorella sp. and the cyanobacteria Arthrospira sp. and Sphaerospermopsis torques-reginae using in situ transesterification assisted by microwave irradiation, an environmentally friendly methodology. As expected from the well-known prevalence of triglycerides over phosphoglycerides in eucaryotic cells, the microalga Chlorella sp. had a higher concentration of lipids than the cyanobacteria prokaryotic cells. Nevertheless, it is possible to observe that the use of cyanobacterial biomass is also a clean and sustainable alternative for the production of high-quality biodiesel.

Our findings on fatty acid profile from commercially available sources of Chlorella sp. and Arthrospira sp. as well as S. torques-reginae are similar to those of previous studies [28-32] The observed fatty acid species are the same; however, small differences between the concentrations reported in the literature (Table S1) and those from the current study may be ascribed to different harvest and reaction procedures $[10,29,30]$. It is worth noting that the fatty acid profile of organisms can be modified not only by varying environmental conditions, but also through genetic means that could further optimize it, enabling their use as a potential biodiesel source [21,24-26,33].

The quality and physicochemical properties of biodiesel is considerably dependent on fatty acid composition used in the transesterification process. In this sense, a high contents of saturated fatty acid (SFA) methyl esters leads to high viscosity biodiesel and, therefore, can cause engine problems and gum formation in vehicles. On the other hand, the presence of long chain fatty acid and polyunsaturated fatty acid (PUFA) methyl esters is associated with low viscosity of the biodiesel $[13,33]$. However, it is noteworthy that a prevalence of PUFAs can lead to oxidative degradation processes, thus affecting the overall biodiesel quality. In this sense, the quality of the biodiesel produced from the strains investigated in this study would be suitable for use as an engine biofuel, since in the samples, there was a balance between saturated and unsaturated fatty acids similar to that of biodiesel obtained from conventional sources. These results indicate the potential of these microorganisms in biodiesel production $[8,34]$.

X-ray spectroscopy analyses were also performed for elemental characterization of biodiesel since the presence of contaminants also interferes with the quality of burning emissions, performance, engine integrity, safety of transport, and even handling of biodiesel. For instance, the presence of transition metals in the synthesized biodiesel can lead to oxidative instability, as these elements are known to initiate the formation of free radicals that decompose unsaturated fatty acids and, therefore, negatively affect biodiesel physicochemical properties [13,27]. Moreover, this information makes it possible to assess the potential of raw materials to produce biodiesel, since the biodiesel quality must meet the regulations of the National Agency for Gas, Petroleum, Natural Gas and Biofuels (ANP).

On the basis of the results of average composition of fatty acids (Table 1) and of the elemental analysis (Table 2), we found that all the raw materials tested in this study proved to be an alternative for biodiesel production, not compromising the transesterification reaction or the parameters required by ANP [33-36].

As a future perspective, the MAE method can be improved and applied to a greater amount of biomass and can be used to check the presence of other fatty acids in different microorganisms, in addition to expanding the study to other microalgae and cyanobacteria of environmental importance. Moreover, the present study was carried out only on a 
laboratory scale; therefore, the next steps would be performing the experiments at an industrial level and evaluating the costs of producing biodiesel from the strains under study.

\section{Conclusions}

Biodiesel production from the cyanobacteria tested in this study (Arthrospira sp. and Sphaerospermopsis torques-reginae) was as promising as that from the microalga Chlorella sp. Their abundant proliferation in eutrophic environments and the balance between saturated and unsaturated fatty acids in both types of biomass led to an adequate quality of biodiesel. Moreover, the microwaved-assisted extraction method was proven to be an alternative for the extraction and synthesis of biodiesel in one pot, reducing the costly steps found in conventional procedures.

Furthermore, the low amounts of elements in the biomass of the studied strains are expected to imply low risks of affecting the quality of burning emissions, performance, engine integrity, safety of transport, and handling of biodiesel.

The use of microwave, $X$-ray, and GC techniques allowed for a quick extraction and identification of important lipids in biodiesel obtaining. For all these aspects, this study adds important information about "green techniques" to produce biofuels and aims to improve biotechnological applications of cyanobacteria and microalgae.

Supplementary Materials: The following supporting information can be downloaded at: https: / www. mdpi.com/article/10.3390/app12052407/s1, Table S1: Composition of fatty acids (\% area) reported in the literature.

Author Contributions: All authors contributed to the study conceptualization and design. Material preparation, data collection, and analyses were performed by L.G.G.B., J.A.M., L.M.B. and A.O.d.S.; J.A.M. and L.M.B. wrote the first draft of the manuscript, and all authors commented on previous versions of the document and revised it; E.P., A.C. and C.M.P.d.P. were responsible for funding acquisition. All authors have read and agreed to the published version of the manuscript.

Funding: This research was funded by FAPESP (Research Support Foundation of the São Paulo State), grant number 2021/00149-0; CNPq (Conselho Nacional de Desenvolvimento Científico e Tecnológico), grant numbers 439065/2018-6, 465450/2014-8, 439065/2018-6, and 313970/2020-3; CAPES (Coordination for the Improvement of HigherLevel Personnel), grant numbers 380746/2020-4 and 88887.144847/2017-00; and the University of São Paulo, grant number 2021.1.307.64.8. Projetos Integrados de Pesquisa em Áreas Estratégicas_PIPAE (bolsa No. 2021.1.10424.1.9), Programa Santander Políticas Públicas—Desafio USP: Cidades Sustentáveis (bolsa No. 1423.1.2021) e Fundação Universidade de São Paulo-FUSP (Projeto \#1979).

Institutional Review Board Statement: Not applicable.

Informed Consent Statement: Not applicable.

Data Availability Statement: Data are available under request. Please contact the corresponding author.

Acknowledgments: The authors are thankful for the funding agencies FAPERGS, FAPESP, and CNPq for the universal project and fellowship (439065/2018-6, 2021/00149-0 and 380746/2020-4, respectively), CAPES for the project and fellowship (88887.636278/2021-00), and University of São Paulo for the project and fellowship (2021.1.307.64.8).

Conflicts of Interest: The authors declare no conflict of interest.

\section{References}

1. Patil, P.D.; Gude, V.G.; Mannarswamy, A.; Cooke, P.; Munson-McGee, S.; Nirmalakhandan, N.; Lammers, P.; Deng, S. Optimization of Microwave-Assisted Transesterification of Dry Algal Biomass Using Response Surface Methodology. Bioresour. Technol. 2011, 102, 1399-1405. [CrossRef] [PubMed]

2. Velasquez-Orta, S.B.; Lee, J.G.M.; Harvey, A. Alkaline in Situ Transesterification of Chlorella vulgaris. Fuel 2012, 94, 544-550. [CrossRef]

3. Tsigie, Y.A.; Huynh, L.H.; Ismadji, S.; Engida, A.M.; Ju, Y.-H. In Situ Biodiesel Production from Wet Chlorella vulgaris under Subcritical Condition. Chem. Eng. J. 2012, 213, 104-108. [CrossRef]

4. Huang, D.; Zhou, H.; Lin, L. Biodiesel: An Alternative to Conventional Fuel. Energy Procedia 2012, 16, 1874-1885. [CrossRef] 
5. Kapoore, R.V.; Butler, T.O.; Pandhal, J.; Vaidyanathan, S. Microwave-Assisted Extraction for Microalgae: From Biofuels to Biorefinery. Biology 2018, 7, 18. [CrossRef]

6. Mata, T.M.; Martins, A.A.; Caetano, N.S. Microalgae for Biodiesel Production and Other Applications: A Review. Renew. Sustain. Energy Rev. 2010, 14, 217-232. [CrossRef]

7. Delucchi, M.A. A Lifecycle Emissions Model(lem): Lifecycle Emissions from Transportation Fuels, Motor Vehicles, Transportation Modes, Electricity Use, Heating and Cooking Fuels, and Materials. 2003, p. 445. Available online: https://escholarship.org/uc/ item/9vr8s1bb\#main (accessed on 24 October 2021).

8. Li, Y.; Horsman, M.; Wu, N.; Lan, C.Q.; Dubois-Calero, N. Biofuels from Microalgae. Biotechnol. Prog. 2008, 24, 815-820. [CrossRef]

9. Wang, B.; Li, Y.; Wu, N.; Lan, C.Q. CO 2 Bio-Mitigation Using Microalgae. Appl. Microbiol. Biotechnol. 2008, 79, 707-718. [CrossRef]

10. Martínez, N.; Callejas, N.; Morais, E.G.; Vieira Costa, J.A.; Jachmanián, I.; Vieitez, I. Obtaining Biodiesel from Microalgae Oil Using Ultrasound-Assisted in-Situ Alkaline Transesterification. Fuel 2017, 202, 512-519. [CrossRef]

11. Li, Y.; Horsman, M.; Wang, B.; Wu, N.; Lan, C.Q. Effects of Nitrogen Sources on Cell Growth and Lipid Accumulation of Green Alga Neochloris oleoabundans. Appl. Microbiol. Biotechnol. 2008, 81, 629-636. [CrossRef]

12. Chee Loong, T.; Idris, A. Rapid Alkali Catalyzed Transesterification of Microalgae Lipids to Biodiesel Using Simultaneous Cooling and Microwave Heating and Its Optimization. Bioresour. Technol. 2014, 174, 311-315. [CrossRef] [PubMed]

13. Berneira, L.M.; Rockembach, C.T.; da Silva, C.C.; de Freitas, S.C.; Rosa, B.N.; Pinto, E.; Anjos, F.M.; dos Santos, M.A.Z.; de Pereira, C.M.P. Employment of Thermal Analysis Applied to the Oxidative Stability Evaluation of Biodiesel Using Chalcone Analogues. J. Therm. Anal. Calorim. 2021, 146, 1473-1482. [CrossRef]

14. Bortoli, S.; Oliveira-Silva, D.; Krüger, T.; Dörr, F.A.; Colepicolo, P.; Volmer, D.A.; Pinto, E. Growth and Microcystin Production of a Brazilian Microcystis aeruginosa Strain (LTPNA 02) under Different Nutrient Conditions. Revista Brasileira de Farmacognosia 2014, 24, 389-398. [CrossRef]

15. Fernandes, K.A.; Pinto, E.; Ferraz, H.G.; Vereau, F. Availability of Guanitoxin in Water Samples Containing Sphaerospermopsis torques-reginae Cells Submitted to Dissolution Tests. Pharmaceuticals 2020, 13, 402. [CrossRef] [PubMed]

16. Shirai, M.; Matumaru, K.; Ohotake, A.; Takamura, Y.; Aida, T.; Nakano, M. Development of a Solid Medium for Growth and Isolation of Axenic Microcystis Strains (Cyanobacteria). Appl. Environ. Microbiol. 1989, 55, 2569-2571. [CrossRef] [PubMed]

17. Bligh, E.G.; Dyer, W.J. A Rapid Method of Total Lipid Extraction and Purification. Can. J. Biochem. Physiol. 1959, 37, 911-917. [CrossRef]

18. Kumari, N.; Singh, R.K. Bio-Diesel Production from Airborne Algae. Environ. Chall. 2021, 5, 100210. [CrossRef]

19. Cancela, A.; Maceiras, R.; Urrejola, S.; Sanchez, A. Microwave-Assisted Transesterification of Macroalgae. Energies 2012, 5, 862-871. [CrossRef]

20. Ichihara, K.; Fukubayashi, Y. Preparation of Fatty Acid Methyl Esters for gas-Liquid Chromatography. J. Lipid Res. 2010, 51, 635-640. [CrossRef]

21. Fazril, I.; Shamsuddin, A.H.; Nomanbhay, S.; Kusomo, F.; Hanif, M.; Ahmad Zamri, M.F.M.; Akhiar, A.; Ismail, M.F. MicrowaveAssisted in Situ Transesterification of Wet Microalgae for the Production of Biodiesel: Progress Review. IOP Conf. Ser. Earth Environ. Sci. 2020, 476, 012078. [CrossRef]

22. Pacheco, B.S.; da Silva, C.C.; de Freitas, S.C.; Berneira, L.M.; da Silva, V.L.; Winkel, K.; Ferreira, L.B.; de Pereira, C.M.P. Employment of Alternative Raw Materials for Biodiesel Synthesis. In Increased Biodiesel Efficiency: Alternatives for Production, Stabilization, Characterization and Use of Coproduct; Trindade, M., Ed.; Springer International Publishing: Cham, Switzerland, 2018; pp. 33-55; ISBN 978-3-319-73552-8.

23. Parial, D.; Patra, H.K.; Roychoudhury, P.; Dasgupta, A.K.; Pal, R. Gold Nanorod Production by Cyanobacteria-A Green Chemistry Approach. J. Appl. Phycol. 2012, 24, 55-60. [CrossRef]

24. Wang, B.; Li, Y.; Zheng, J.; Hu, Y.; Wang, X.; Hu, B. Efficient Removal of U(VI) from Aqueous Solutions Using the Magnetic Biochar Derived from the Biomass of a Bloom-Forming Cyanobacterium (Microcystis aeruginosa). Chemosphere 2020, $254,126898$. [CrossRef] [PubMed]

25. Xu, H.; Miao, X.; Wu, Q. High Quality Biodiesel Production from a Microalga Chlorella protothecoides by Heterotrophic Growth in Fermenters. J. Biotechnol. 2006, 126, 499-507. [CrossRef] [PubMed]

26. Romano, I.; Bellitti, M.R.; Nicolaus, B.; Lama, L.; Manca, M.C.; Pagnotta, E.; Gambacorta, A. Lipid Profile: A Useful Chemotaxonomic Marker for Classification of a New Cyanobacterium in Spirulina Genus. Phytochemistry 2000, 54, 289-294. [CrossRef]

27. Ben-Amotz, A.; Tornabene, T.G.; Thomas, W.H. Chemical Profile of Selected Species of Microalgae with Emphasis on Lipids. J. Phycol. 1985, 21, 72-81. [CrossRef]

28. da Silva, C.C.; Pacheco, B.S.; de Freitas, S.C.; Berneira, L.M.; dos Santos, M.A.Z.; Pizzuti, L.; de Pereira, C.M.P. Hydroxychalcones: Synthetic Alternatives to Enhance Oxidative Stability of Biodiesel. In Increased Biodiesel Efficiency: Alternatives for Production, Stabilization, Characterization and Use of Coproduct; Trindade, M., Ed.; Springer International Publishing: Cham, Switzerland, 2018; pp. 81-110. ISBN 978-3-319-73552-8.

29. Nayak, S.N.; Bhasin, C.P.; Nayak, M.G. A Review on Microwave-Assisted Transesterification Processes Using Various Catalytic and Non-Catalytic Systems. Renew. Energy 2019, 143, 1366-1387. [CrossRef]

30. Sarsekeyeva, F.; Zayadan, B.K.; Usserbaeva, A.; Bedbenov, V.S.; Sinetova, M.A.; Los, D.A. Cyanofuels: Biofuels from Cyanobacteria. Reality and Perspectives. Photosynth. Res. 2015, 125, 329-340. [CrossRef] 
31. Passos, L.S.; Almeida, É.C.; de Pereira, C.M.P.; Casazza, A.A.; Converti, A.; Pinto, E. Chemical Characterization of Microcystis aeruginosa for Feed and Energy Uses. Energies 2021, 14, 3013. [CrossRef]

32. Gülyurt, M.Ö.; Özçimen, D.; İnan, B. Biodiesel Production from Chlorella protothecoides Oil by Microwave-Assisted Transesterification. Int. J. Mol. Sci. 2016, 17, 579. [CrossRef]

33. Sharma, A.K.; Sahoo, P.K.; Singhal, S.; Joshi, G. Exploration of Upstream and Downstream Process for Microwave Assisted Sustainable Biodiesel Production from Microalgae Chlorella vulgaris. Bioresour. Technol. 2016, 216, 793-800. [CrossRef]

34. Choe, E.; Min, D.B. Comprehensive Food Science and Food Safety Reviews in Mechanisms and Factors for Edible Oil Oxidation. Compr. Rev. Food Sci. Food Saf. 2006, 5, 169-186. [CrossRef]

35. Agência Nacional do Petróleo, Gás Natural e Biocombustíveis. Resolução ANP No 45 de 25/08/2014; Agência Nacional do Petróleo, Gás Natural e Biocombustíveis: Brasilia, Brazil, 2014. Available online: https:/ / www.gov.br/anp/pt-br/canais_atendimento/ imprensa/noticias-comunicados/anp-publica-resolucao-sobre-especificacao-do-biodiesel (accessed on 2 November 2021).

36. Wu, H.; Miao, X. Biodiesel Quality and Biochemical Changes of Microalgae Chlorella pyrenoidosa and Scenedesmus obliquus in Response to Nitrate Levels. Bioresour. Technol. 2014, 170, 421-427. [CrossRef] [PubMed] 